\title{
Determination of Phytoremediation Potential of Some Selected African Plants
}

\author{
${ }^{1}$ ezeudu E. C., ${ }^{1}$ adisianya C. P. and ${ }^{2}$ Oli C. C. \\ ${ }^{1}$ department of Chemistry Paul University, Awka, Anambra State, Nigeria. \\ ${ }^{2}$ department of Pure and Industrial Chemistry, Nnamdi Azikiwe University, Awka, Nigeria.
}

\begin{abstract}
Four different plants namely, Eupatorium odoratum, Ricinus communis, Amaranthus spinosus and Vigna unguiculata were used to study and provide data for the principle of phytoremediation using salts of cadmium, copper and lead. Results obtained using Atomic Absorption Spectrophotometer after sixteen weeks of growth of the named plants indicate that appreciable phytoremediation is exhibited as follows:

Eupatorium odoratum ( $\mathrm{Cd}$, all parts; $\mathrm{Cu}$, root: $\mathrm{Pb}$, root and stem), Ricinus communis ( $\mathrm{Cd}$, root: $\mathrm{Cu}$, leaves: $\mathrm{Pb}$, root and stem), Vigna Unguiculata(Cd, leaves: $C u$, leaves: $P b$, leaves), Amaranthus spinosus(Cd, root:Pb, root and stem).
\end{abstract}

Keywords: Eupatorium odoratum, Ricinus communis, Amaranthus spinosus, Vigna unguiculata and phytoremediation.

\section{Introduction}

Phytoremediation is a general term used to describe various mechanisms by which plants alter the chemical composition of the soil mixture in which they are growing. Essentially, it is the use of green plants to clean up contaminated soils, and/or the environment.

That Phytoremediation is beneficial to both human health and the environment has been acknowledged, limiting factors not withstanding. Problems start with plant selection, in which the use of native plant species has been advocated. These native plants can be envisaged to require less maintenance and present fewer environmental and human risks than would non-native or genetically altered species. Secondly, effective Phytoremediation requires that root systems extend into the contaminated region and that the contaminated the contaminants be brought within the range of the rhizosphere.

On the bases of the above, and in the absence of any special sites marked out by any agency for study/clean up exercise, it was thought that study of some native plants would be undertaken to record their response to the presence of some common heavy metals reported to have toxic effects on plants or even humans.

The plants selected for study are Eupatorium odoratum, Ricinus communis, Vigna Unguiculata and Amaranthus spinosus. The four selected plants have well developed fibrous root systems, which are speculated to constitute a rich variety for adequate study. Apart from this well developed fibrous root system, Eupatorium odoratum is known to be tolerant to harsh climatic conditions, and has been found in virtually all the vegetative belts of Nigeria. Again, since different parts store absorbed metals at different tissues, it would be important to see if the selected plant which are easily propagated, could store these metals mostly in their fibrous root system and/or any other easily accessible tissue such as the leaf system. In what follows, synthetic samples will be used as substrate contaminant while the various plant tissues will be harvested for their metal contents. Such tissues include: roots, stems and leaves.

\section{Materials And Reagents}

Plastic containers, volumetric flasks, watering can, electric furnace, AAS, measuring cylinder, $\mathrm{Pb}\left(\mathrm{NO}_{3}\right)_{2}$, $\mathrm{Cd}\left(\mathrm{NO}_{3}\right) \cdot 4 \mathrm{H}_{2} \mathrm{O}, \mathrm{CuSO}_{4} \cdot 5 \mathrm{H}_{2} \mathrm{O}, \mathrm{HNO}_{3}$, deionized water

\section{Method}

The seedlings of Eupatorium odoratum, and the seeds of Ricinus communis, Vigna Unguiculata and Amaranthus spinosus were each sown in four different containers of sand of which three had been inoculated with $40 \mathrm{~cm}^{3}$ of $0.3 \mathrm{M} \mathrm{Cd}\left(\mathrm{NO}_{3}\right) \cdot 4 \mathrm{H}_{2} \mathrm{O}, 40 \mathrm{~cm}^{3}$ of $0.3 \mathrm{M} \mathrm{CuSO}_{4} .5 \mathrm{H}_{2} \mathrm{O}$ and $40 \mathrm{~cm}^{3}$ of $0.3 \mathrm{M} \mathrm{Pb}\left(\mathrm{NO}_{3}\right)_{2}$ respectively, while the fourth container was not inoculated so that it serves as control. The plants were harvested by uprooting after sixteen weeks of planting. The harvested plants parts were washed with deionized water and each dried separately in a room with labelled trays. Each dried part was ashed in an electric furnace at a $450^{\circ} \mathrm{C}$ for two hours and allowed to cool. Then it was digested with $20 \mathrm{~cm}^{3}$ of concentrated $\mathrm{HNO}_{3}$ which was aided by heat from electric heater for about two hours. The digested samples were each subsequently heated to dryness and made up with water until there was little or no evolution of white fumes. Deionized water was then added after heating and cooling and the resulting solution was filtered. The residue from the filtration was thoroughly 
washed. The combined filtrate and wash liquid were eventually made up to $50 \mathrm{~cm} 3$ in a volumetric flask. Each combined filtrate was stored in a plastic bottle and subsequently analyzed using Atomic Absorption Spectrophotometer.

\section{Results And Discussion}

Table I: Elemental Analysis of Soil Sample prior to Planting

$\begin{array}{lr}\text { Element } & \text { Concentration }(\mathrm{ppm}) \\ \mathrm{Cd} & 1.82 \\ \mathrm{Cu} & 2.37 \\ \mathrm{~Pb} & 4.41\end{array}$

Table II: Metal uptake data for Eupatorium odoratum

Plant part

Root

Stem

Leaves

Plant part

Root

Stem

Leaves

Plant part

Root

Stem

Leaves

Plant part

Root

Stem

Leaves

Plant part

Root

Stem

Leaves

Plant part

Root

Stem

Leaves

(a).Control: watered with deionized water only
$\mathrm{Cd}(\mathrm{ppm})$
$\mathrm{Cu}(\mathrm{ppm})$
$\mathrm{Pb}(\mathrm{ppm})$
0.24
0.52
1.02
0.36
0.30
1.78
0.38
0.90
0.13

(b). Soil initially spiked with salt solutions

$\begin{array}{ccc}\mathrm{Cd}(\mathrm{ppm}) & \mathrm{Cu}(\mathrm{ppm}) & \mathrm{Pb}(\mathrm{ppm}) \\ 10.96 & 5.86 & 12.65 \\ 49.84 & 0.96 & 7.76 \\ 37.15 & 2.11 & 2.93\end{array}$

Table III: Metal uptake data for Amaranthus spinosus

(a). Control

$\mathrm{Cd}(\mathrm{ppm})$
0.16
0.32
0.51

$\mathrm{Cu}(\mathrm{ppm})$
0.21
0.22
0.29

$\mathrm{Pb}(\mathrm{ppm})$

0.30

0.32

0.79

(b). Soil spiked with salt solutions

$\begin{array}{ccc}\mathrm{Cd}(\mathrm{ppm}) & \mathrm{Cu}(\mathrm{ppm}) & \mathrm{Pb}(\mathrm{ppm}) \\ 3.70 & 1.42 & 3.97 \\ 0.42 & 1.44 & 1.57 \\ 3.91 & 1.48 & 1.64\end{array}$

Table IV: Metal uptake data for Ricinus communis

(a). Control

$\begin{array}{ccc}\mathrm{Cd}(\mathrm{ppm}) & \mathrm{Cu}(\mathrm{ppm}) & \mathrm{Pb}(\mathrm{ppm}) \\ 0.18 & 0.22 & 0.69 \\ 0.56 & 0.21 & 0.61 \\ 0.64 & 0.16 & 1.29\end{array}$

(b). Soil spiked with salt solution

$\begin{array}{ccc}\mathrm{Cd}(\mathrm{ppm}) & \mathrm{Cu}(\mathrm{ppm}) & \mathrm{Pb}(\mathrm{ppm}) \\ 5.13 & 0.46 & 15.56 \\ 1.27 & 0.72 & 5.00 \\ 2.20 & 6.85 & 4.13\end{array}$

Table V: Metal uptake data for Vigna Unguiculata.

(a). Control

$\begin{array}{cccc}\text { Plant part } & \mathrm{Cd}(\mathrm{ppm}) & \mathrm{Cu}(\mathrm{ppm}) & \mathrm{Pb}(\mathrm{ppm}) \\ \text { Root } & 0.056 & 0.09 & 0.48 \\ \text { Stem } & 0.19 & 0.15 & 0.40\end{array}$


Leaves

Plant part
Root
Stem

Leaves
0.12

0.46

(b). Soil spiked with salt solution

$\begin{array}{cc}\mathrm{Cd}(\mathrm{ppm}) & \mathrm{Cu}(\mathrm{ppm}) \\ 1.14 & 1.11 \\ 1.13 & 0.52 \\ 2.73 & 4.20\end{array}$

1.30

$\mathrm{Pb}(\mathrm{ppm})$
0.96
1.02
8.72

Eupatorium odoratum
$\mathrm{Cd}$
$\mathrm{Cu}$
$\mathrm{Pb}$

$\mathrm{Cd}$

$\mathrm{Cu}$ $\mathrm{Pb}$

$\mathrm{Cd}$

$\mathrm{Cu}$

$\mathrm{Pb}$

$\mathrm{Cd}$

$\mathrm{Cu}$

$\mathrm{Pb}$

Table VI: Relative metal uptake data.

$\begin{array}{ccc}\text { root } & \text { stem } & \text { leaves } \\ +10.72 & +49.48 & +36.77 \\ +5.34 & +0.66 & +1.21 \\ +11.63 & +5.98 & +2.80\end{array}$

\section{Amaranthus spinosus}

$+3.54$

$+1.21$

$+3.47$

$+0.10$

$+1.22$

$+1.25$

$+3.40$

$+1.18$

$+0.85$

\section{Ricinus communis}

$+4.95$

$+0.24$

$+0.71$

$+0.51$

$+1.56$

$+14.87$

$+4.39$

$+6.69$

$+2.84$

Vigna unguiculata

$\begin{array}{lll}+1.08 & +0.94 & +2.61 \\ +1.02 & +0.37 & +3.74 \\ +0.48 & +0.62 & +7.42\end{array}$

Table VI gives the summary of the relative metal uptake data. These data have been generated relative to 'control' value as baseline. The metal uptake values are all higher than those in the 'control', and these are indicated by the positive (+) sign. The relative uptake values range from +0.10 (the lowest) to +49.48 (the highest). Our search of literature so far indicates that there is no generally accepted background concentration of most metals in soils; classification of these relative metal uptake values into 'high' or 'low' would thus be arbitrary. Alloway has provided some helpful data, and these are abridged for $\mathrm{Cd}, \mathrm{Cu}$ and $\mathrm{Pb}$ in table VII.

Table VII: Selected values of some heavy metals from Canadian environment.

\begin{tabular}{|l|l|l|ll|}
\hline Metal & \multicolumn{2}{|c|}{ Concentration (ppm) } & Plant leaves \\
\hline & Background (soil) & Agriculture & Normal & Toxic \\
\hline $\mathrm{Cd}$ & 0.5 & 3 & $0.1-24$ & $5-30$ \\
\hline $\mathrm{Cu}$ & 30 & 150 & $5-20$ & $20-100$ \\
\hline $\mathrm{Pb}$ & 25 & 305 & $5-10$ & $30-300$ \\
\hline
\end{tabular}

Undoubtedly, $\mathrm{Cd}, \mathrm{Cu}$ and $\mathrm{Pb}$ have been classed among the most toxic heavy metals, and it is not surprising that several studies have been devoted to various aspects of their bioavailability and effects. It should be thus be possible to compare the experimental uptake values obtained for these metals from the experiments with these tabulated results. Secondly, a plant that may be classed as bioaccumulator must be able to tolerate high levels of the element in root and shoot cells, and in addition must have the ability to translocate the element from roots to shoots at high rates, the root concentrations being about ten times higher than shoot concentrations. And in hyperaccumulation, shoot metal concentration exceeding root levels. Therefore, from the uptake data of the three heavy metals studied here, inferences may be drawn as hereunder for each of the four plants.

(I). Amaranthus spinosus: This plant has demonstrated a positive relative uptake of each of the three heavy metals but cannot be said to be a bioaccumulator of any of them. In no case is the concentration of each metal up to ten times as high in the root compared with the shoot. In addition, few of the shoot concentrations exceed those of the root. Virtually all metal concentrations are within the background level.

(II). Ricinus communis: This plant fits into an accumulator for $\mathrm{Cu}$ (root; 0.24 and leaves; 6.69) giving a ratio of about 1 to 28 in favour of the leaves. This makes it a hyperaccumulator for $\mathrm{Cu}$. It is also a mild bioaccumulator for $\mathrm{Pb}$, the root concentration being about five times higher than that of the shoot. 
(III). Vigna unguiculata: This is a strong bioaccumulator of $\mathrm{Pb}$ for which it is in fact a hyperaccumulator: the shoot to root concentration ratio far exceeds ten.

(IV). Eupatorium odoratum shows positive uptake values for both $\mathrm{Cd}$ and $\mathrm{Pb}$; while the former demonstrates a higher value in the leaves than in the root, the latter, $\mathrm{Pb}$, clearly has a much higher value in the root than in the shoot. E. Odoratum can thus be described as a bioaccumulator for both $\mathrm{Cd}$ and $\mathrm{Pb}$ but a hyperaccumulator for neither.

\section{Conclusion}

All the plants studied have demonstrated that they can tolerate the salt admixtures without adverse effect on each of them. The conclusion is thus inescapable that three of the plants fit into the classification of bioaccumulators, namely, Ricinus communis for $\mathrm{Cu}$ for which it can act as a hyperaccumulator; it is also a bioaccumulator for $\mathrm{Pb}$. Vigna unguiculata is a strong bioaccumulator for $\mathrm{Pb}$ (also a hyperaccumulator for it), while Eupatorium odoratum is a bioaccumulator for both $\mathrm{Cd}$ and $\mathrm{Pb}$ but cannot be described as a hyperaccumulator for either. Amaranthus spinosu has not demonstrated any tendency to bioaccumulate any of the three heavy metals studied.

\section{References}

[1]. Raskin,I and Ensley, B.D. (Eds). Phytoremediation of toxic metals: using plants to clean up the environment. John Wiley \& Sons, Inc, 2000

[2]. U.S Environmental Protection Agency (2000). Publication No.600/AR-99/107, Cinannti, OH

[3]. Alloway, B.J (1995). Heavy Metals in Soils. $2^{\text {nd }}$ edition. Blackie \& Sons, Glasgow

[4]. Dzantor, E.K and Beanichamp, R.G (2000). Phytoremediation Part 1. Journal of the National Association of Environmental Professionals. 4,77-87.

[5]. Cunningham, S; Germani, S and Huang, J.(1997). Plant Based Soil Remediation: Phytoextracting Pb-contaminated soils using novel techniques. Support Central Research and Development.Newark

[6]. Scheper, T. (2002). Advances in Biochemistry/Biotechnology, Springer Verlag, Berlin, Heidelberg, New York, vol 78 pp 14, 20, 100,107

[7]. Jaako, P. (1991)Chemical Ecotoxicology, Lewis Publishers, pp13-15

[8]. Brook,R.R. (1998). Plants that hyperaccumulate heavy metals, CAB International, New York, pp 1-3

[9]. U.S.E.P.A (1993) Cleaning up the Nation's Waste sites. Office of Solid and Waste Emergency Response Technology Innovation, Washington DC

[10]. Baker,A; Mcgrath,S and Reeves, R. (1991). In situ decontamination of Heavy Metal polluted soils Using Metal-Accumulating Plants - A Feasibility Study. pp 600-605 